\begin{tabular}{lllll} 
ZAPISKI HISTORYCZNE & $-\underset{\text { TOM }}{\text { Zeszyt } 3}$ \\
\hline
\end{tabular}

http://dx.doi.org/10.15762/ZH.2014.05

ADAM SZEFER (Niemcz, Bydgoszcz)

\title{
CASUS BYDGOSKIEGO ŻEBRAKA JAKUBA ŻORAWSKIEGO PRZYCZYNEK DO PROBLEMU ŻEBRACTWA W NOWOŻYTNEJ RZECZYPOSPOLITEJ
}

Słowa kluczowe: Bydgoszcz, testament, ubóstwo, biedota miejska, pauperes, ubodzy w czasach staropolskich

Epoka nowożytna odziedziczyła po czasach średniowiecza nabrzmiały problem żebractwa. Żebraniną, oprócz „klasycznych” żebraków, zajmowali się również pensjonariusze ówczesnych szpitali, a czasem także biedota miejska, zmuszona do tego w okresie złej koniunktury gospodarczej. Do stania się żebrakiem prowadziły zwykle naturalne procesy, takie jak: brak oparcia w rodzinie, śmierć najbliższych, kalectwo czy choroba (np. ślepota) i wynikające z nich problemy finansowe. W czasach nowożytnych bieda i choroba nadawały prawo do korzystania z jałmużny oraz opieki szpitalnej, ale równocześnie piętnowały ludzi. Szpital lub przytułek wybierały przede wszystkim niższe warstwy ludności miejskiej. Na dodatek w tych instytucjach nie było możliwości zapewnienia opieki wszystkim potrzebującym. Tym samym za pomocą żebraniny, oprócz stałej grupy żebraków, środki do życia musieli zdobyć ci, którzy nie znaleźli miejsca w szpitalach, oraz ci, którzy pochodzili spoza danego miasta ${ }^{1}$.

Zdarzało się również, że wysłużeni gospodarze po oddaniu gospodarstwa w ręce dzieci zmuszeni byli do przyjęcia żebraczego trybu życia ${ }^{2}$. W skrajnych zaś przypadkach, ku zgorszeniu innych przedstawicieli tego stanu, nawet szlachta parała się tym sposobem zarobkowania (byli to przeważnie przedstawiciele najbiedniejszych rodzin szlacheckich pochodzących z Mazowsza lub Podlasia) ${ }^{3}$. Wreszcie, grono żebraków zasilali wszelkiej maści próżniacy. Stąd widoczny już w średniowieczu, a bardzo wyeksponowany w czasach nowożytnych problem „nieuczciwych potrzebujących"4.

\footnotetext{
${ }^{1}$ Bronisław Geremek, Ludzie marginesu w średniowiecznym Paryżu. XIV-XV wiek, Poznań 2003, s. 146-153.

${ }^{2}$ Stanisław Grodziski, Ludzie luźni. Studium z historii państwa i prawa polskiego, Kraków 1961, s. 60; Bohdan Baranowski, Ludzie gościńca w XVII-XVIII wieku, Łódź 1986, s. 121.

${ }^{3}$ Ibid., s. 131.

${ }^{4}$ Bronisław Geremer, Litość i szubienica. Dzieje nędzy i miłosierdzia, Warszawa 1989, s. 34-35.
} 
Z definicji słowa „żebrak” wynika, że zazwyczaj nie miał on majątku, a co najwyżej był on bardzo niewielki i ograniczał się do skromnych ruchomości ${ }^{5}$. Na tym tle bardzo interesujący i zupełnie wyjątkowy jest przypadek żebraka Jakuba Żorawskiego, mieszkańca szesnastowiecznej Bydgoszczy. Pozostawił on po sobie testament, z którego wynika, że był posiadaczem skromnych dóbr ruchomych (głównie odzienia), a przede wszystkim nieruchomości zwanej w jego ostatniej woli „domkiem”.

Testament ten znajduje się w rękopiśmiennej księdze Liber testamentorum civilium Bidgostiensium przechowywanej w Archiwum Państwowym w Bydgoszczy ${ }^{7}$. Powstanie księgi, zawierającej - zgodnie z tytułem - testamenty mieszkańców Bydgoszczy, wiąże się z uczczeniem przez rajców oraz ławników pamięci ks. Jana Fabiusa z Bobowa, proboszcza bydgoskiej fary i oficjała biskupa kujawskiego. Dnia 9 VI 1581 r. oblatowano w tej księdze testament duchownego, który jest pierwszym dokumentem do niej wpisanym ${ }^{8}$. Rzecz jasna owo „uczczenie pamięci” ks. Fabiusa nie miało tylko wymiaru moralnego, ponieważ posłużyło ono mieszczanom za asumpt do założenia księgi zawierającej testamenty oraz inwentarze mienia ${ }^{9}$. Księgę doprowadzono do $1621 \mathrm{r}^{10}$ Jest ona w pełni oryginalna i nie zawiera późniejszych dopisków.

Testament J. Żorawskiego został spisany około godziny 8.00, w czwartą niedzielę adwentu (22 XII) 1585 r. Rzecz działa się w domu testatora („in domo sua”)

${ }^{5}$ Andrzej Karpiński, Pauperes. O mieszkańcach Warszawy XVI i XVII wieku, Warszawa 1983, s. $226,308-310$.

${ }^{6}$ Testamenty ludzi marginesu społecznego nie są czymś niespotykanym, jednakże odnajduje się je bardzo rzadko. A. Karpiński, badając zjawisko prostytucji w dużych ośrodkach miejskich Rzeczypospolitej w XVI i XVII w. oraz pozycję kobiet w miastach polskich od połowy XVI do końca wieku XVII, odnalazł kilka testamentów przedstawicielek marginesu społecznego (żebraczek kościelnych, pensjonariuszek przytułków oraz kryminalistek i prostytutek), jednak w żadnym ze wspomnianych przypadków nie było mowy o tym, by osoby te miały tak znaczący majątek, jakim była nieruchomość w obrębie murów miejskich, por. Andrzej KaRPIŃsKI, Prostytucja $w$ dużych miastach polskich $w$ XVI i XVII wieku, Kwartalnik Historii Kultury Materialnej, R. 36: 1988, nr 2, s. 292, 297; idem, Kobieta w mieście polskim w drugiej połowie XVI i w XVII wieku, Warszawa 1995, s. 255.

${ }^{7}$ Archiwum Państwowe w Bydgoszczy (dalej cyt. APB), Akta miasta Bydgoszczy (dalej cyt. AMB), sygn. 18: „Liber testamentorum civilium Bidgostiensium”, k. 40v-41v.

${ }^{8}$ Ibid., k. 1, 2-4v; Ksiega testamentów obywateli bydgoskich (dalej cyt. KTOB), wyd. Zygmunt Malewski, Przegląd Bydgoski, R. 3: 1935, z. 1-2, s. 43-44, 52-53; Ryszard Kabaciński, Parafia, wspólnoty zakonne i kaplice przełomu XII i XIII wieku do 1771 roku, [in:] Kościół katolicki w Bydgoszczy. Kalendarium, red. Janusz KutTa, Bydgoszcz 1997, s. 54-55.

${ }^{9}$ Ponieważ stan zachowania bydgoskich archiwaliów proweniencji miejskiej nie jest najpełniejszy, nie ma całkowitej pewności co do tego, czy omawiana tu księga była pierwszą księgą testamentów w Bydgoszczy. $Z$ treści dokumentów wpisanych do omawianego woluminu (oblaty trzech aktów ostatniej woli spisanych w latach 1564-1578; APB, AMB, sygn. 18, k. 10-10v; k. 16v-18; k. 18-18v) jasno wynika, że bydgoszczanie posługiwali się testamentami przed jego powstaniem. Tym samym pozostaje pytanie, czy wcześniej istniała osobna seria ksiąg przeznaczonych do wpisywania aktów ostatniej woli, czy też nie. Zagadnienie to póki co pozostanie nierozstrzygnięte.

${ }^{10} \mathrm{~W}$ inwentarzu archiwalnym oraz w literaturze przedmiotu jako datę końcową przyjęto $1620 \mathrm{r}$. Jednakże po wnikliwej analizie ostatnich, mało czytelnych kart można dojść do wniosku, że sporządzono je w 1621 r., zob. APB, AMB, sygn. 18, k. 217; KTOB, s. 41. 
w Bydgoszczy, w obecności osób urzędowych, świadków oraz beneficjenta tegoż testamentu. Zostali oni wymienieni na końcu dokumentu: „Acta sunt hec anno die ut supra praesentibus famatis Francisco Swincik viceadvocato subdelegato Alberto notario, Joanne Mattheiek Ministeriali quiale Paulo Doniczka sartore, Sebastiano Urbancik figulo, Stanislao Bała testibus [...]"11.

Czy jednak na pewno mamy do czynienia z aktem ostatniej woli żebraka? Moim zdaniem zdecydowanie tak. Wskazują na to: nagłówek testamentu, w którym użyto łacińskiego terminu „mendici” ${ }^{12}$, oraz dwie krótkie frazy tego dokumentu: „bo on będąc żebrakiem ułomnym [...]"13, a także ,jako na żebraka należy [...]"14. Biorąc pod uwagę konwencję, w jakiej sporządzono testament (trzecia osoba liczby pojedynczej), widać, że pisarz starał się w sposób konkretny dać do zrozumienia, czyj akt ostatniej woli wciągał do akt. Dodatkowy dowód na to, że J. Żorawski był żebrakiem, stanowi ustęp z jego testamentu świadczący o sposobie zarobkowania testatora („a chłopięciu Stanisława, co go wodziło, za jego pracę i służbę [...]”)

Na podstawie treści omawianego dokumentu możemy domniemywać, $w$ jaki sposób J. Żorawski stał się żebrakiem ${ }^{16}$. W jego przypadku należy łączyć degradację społeczną z utratą zaplecza społecznego, jakim była rodzina. Zawarte w testamencie frazy: „na najbliższe swe powinowate 3 złote odkazał” ${ }^{17}$ oraz „także i insze rzeczy, które przy Michale Tobole, po śmierci syna jego Jana, morowym powietrzem zmarłego pozostały"18, wskazują na to, że niegdyś testator miał rodzinę: żonę (stąd wspomnienie o powinowatych) oraz syna, który zmarł zapewne podczas zarazy szalejącej w Bydgoszczy w tym samym roku $(1585)^{19}$. Wydaje się, że była to uboga familia. Zapewne rodzice dość szybko oddali swojego syna na przyuczenie do zawodu rzeźniczego Michałowi Tobole ${ }^{20}$. Nie jest jasne, kiedy i w jakich okolicznościach J. Żorawski stracił żonę, w każdym razie nastąpiło to na pewno przed sporządzeniem jego ostatniej woli. Wiadomo natomiast, że przez dłuższy okres życia, liczony w latach, korzystał z jałmużny, na co wskazuje następujący fragment do-

${ }^{11}$ APB, AMB, sygn. 18, k. 41v.

${ }^{12}$ Ibid., k. 40v: „TESTAMENTU[M] OLIM PROVIDI JACOBI ZORAWSKI, MENDICI”.

${ }^{13}$ Ibid., k. 41.

${ }^{14}$ Ibid., k. 41v.

${ }^{15}$ Ibid.

${ }^{16} \mathrm{O}$ tym, że nie był nim od początku swojej egzystencji, świadczy odnotowanie przez pisarza miejskiego jego nazwiska. Większość ówczesnych żebraków pozostawała anonimowa bądź znana była jedynie z imienia, względnie z pseudonimu, zob. A. Karpiński, Pauperes, s. 221.

${ }^{17}$ APB, AMB, sygn. 18, k. 41.

${ }^{18}$ Ibid., k. 41v.

${ }^{19} \mathrm{~W}$ świetle notatki sporządzonej w bydgoskiej księdze grodzkiej z tego czasu (1585-1586) zaraza w 1585 r. pojawiła się w Bydgoszczy około 23 kwietnia (w dzień św. Wojciecha) na przedmieściu (nie podano jakim). Jej apogeum przypadło w lipcu tegoż roku. Wtedy bowiem (5 lipca) zdecydowano o wstrzymaniu działalności urzędu grodzkiego. W świetle tej zapiski zaraza utrzymywała się co najmniej do 11 listopada (do dnia św. Marcina), zob. Archiwum Państwowe w Poznaniu, Księgi sądu i urzędu grodzkiego w Bydgoszczy, sygn. 53/12/0/-/ Bydgoszcz Gr. 13, k. 230, k. 232v.

${ }^{20}$ Michał Toboła był obywatelem bydgoskim, rzeźnikiem (łac. lanio), zob. Maria CzaplicKA-NieDBALSKa, Nazwiska mieszkańców Bydgoszczy od II poł. XV w. do I poł. XVIII w., Bydgoszcz 1996, s. 393. 
kumentu: „z którego domku jeszcze na miłosierne uczynki za jałmużnę, której od ludzi przez kilkanaście mało lat używał"21. Być może wsparcie, które otrzymywał, było efektem żebraniny, która - jak wynika z jego testamentu - trwała do końca życia. Tym samym J. Żorawski jawi się nam jako biedak, który w pewnym momencie swojej egzystencji (nie jest on możliwy do ustalenia) stał się żebrakiem.

Zatem jak brzmiały jego dyspozycje testamentowe?

W pierwszych słowach swej ostatniej woli testator polecił swoją duszę Bogu, po czym wydał następującą dyspozycję dotyczącą swego pogrzebu: „a ciału pogrzeb prze [z] Stanisława Bale, komornika i jego żonę Katarzynę, ich własnym nakładem uczynić prosił, bo on, będąc żebrakiem ułomnym, powiedział, dostatku tego nie mieć, który pogrzeb na cmentarzu u fary sobie obrał"22.

Wspomniani komornicy opiekowali się wcześniej chorującym testatorem. Koszty tej opieki wyliczyli na 10 złotych polskich. Pieniądze te J. Żorawski zapisał im na swoich nieruchomościach: „które t[o] 10 złotych na domku swoim i drugi[ch] jakichkolwiek majętności nieruchomy im zapisuje" ${ }^{23}$. Dodatkowo kierując się wdzięcznością dla tych, którzy udzielali mu jałmużny, oraz miłosierdziem względem ubogich z nieokreślonego szpitala ${ }^{24}$, zapisał na swoim „domku” 7 złotych polskich na obiady dla tychże ubogich, określając również sposób finansowania tych posiłków oraz wyznaczył sumę 3 złotych na rzecz swoich bliżej nieokreślonych powinowatych: „z którego domku jeszcze na miłosierne uczynki za jałmużnę, której od ludzi przez kilkanaście mało lat używał, 7 złotych polskich ubogim na obiady przez tegoż Stanisława Bałę i Katarzynę małżonkę tym obyczajem odkazał, że na każdy rok po talerze starym obiad na ubogie wyprawić mają aż do wydania [p]omienionych 7 złotych. Także też z tego domku ten to Jakub Żorawski na najbliższe swe powinowate 3 złote odkazał, które ten to Stanisław Bała i z żoną swoją, gdy się czy przyjaciele bliżsi ozową, podług jego woli wydać mają" ${ }^{25}$. Na opiekunów i wykonawców tych zaleceń umierający żebrak wyznaczył wspomnianych komorników. W zamian za okazane mu wcześniej miłosierdzie oraz przyszłe wykonanie wszystkich postanowień zapisał im swoje nieruchomości: „a gdy to ten Stanisław Bała, i z żoną swoją uczyni, przy domku i drugich dobrach nieruchomych jako swoich własnych mają zostać i potomkowie jeich"26.

Testator rozdysponował między członków tej rodziny także swoje dobra ruchome. Katarzyna Bała, za dobroć okazywaną żebrakowi Jakubowi, otrzymała pościel

${ }^{21}$ APB, AMB, sygn. 18, k. 41.

${ }^{22}$ Ibid., k. 41.

${ }^{23}$ Ibid.

${ }^{24} \mathrm{~W}$ ówczesnej Bydgoszczy istniały trzy szpitale, wszystkie poza murami miasta, zob. Walentyna Krystyna Korpalska, Sześć wieków opieki zdrowotnej w Bydgoszczy, Toruń 2008, s. 46-55; Radosław Michna, Nie tylko u świętego Ducha - bydgoskie szpitale z XVI-wiecznq metryką, Kronika Bydgoska, t. 32: 2010, s. 79.

${ }^{25}$ APB, AMB, sygn. 18, k. 41.

${ }^{26}$ Ibid. Zapewne pod terminem „drugie dobra nieruchome” testator miał na myśli przydomowy ogródek. 
i inne rzeczy: „Item pościółkę swą ubogą ze wszytkimi aparaty, jako na żebraka należy, Katarzynie komornicy za wymierne posługi i dobrodziejstwa, które u czasu jego choroby jako ojcu czyniła, odkazał"27. Jej mąż Stanisław dostał wszystkie jego ubrania („szaty”). Ich syn zaś, który prowadził tegoż żebraka do bliżej nieokreślonego miejsca, w którym uprawiał swoją działalność, otrzymał część jego ubrań oraz rzeczy, które zostały u Michała Toboły, po śmierci jego syna, który zmarł podczas zarazy: „a chłopięciu Stanisława, co go wodziło za jego pracę i służbę, sukienkę swoją i żupkę także i insze rzeczy, które przy Michale Tobole, po śmierci syna jego Jana, morowym powietrzem zmarłego, pozostały, to wszytko temu chłopięciu odkazał [...]"28. Można dodać, że w momencie sporządzania testamentu żebrak prawdopodobnie nie miał żadnej gotówki. Świadczyć o tym mogą jego legaty, które co prawda zapisał w formie pieniężnej, ale na swojej nieruchomości.

Czy wiemy coś więcej o J. Żorawskim: skąd pochodził oraz w jakich okolicznościach stał się właścicielem nieruchomości, którą w dodatku był w stanie zachować przy sobie?

Nie jest pewne, czy testator był od urodzenia mieszkańcem Bydgoszczy. Jego testament jest zbyt lakoniczny, aby precyzyjnie odpowiedzieć na to pytanie. W pracy Marii Czaplickiej-Niedbalskiej, opartej na wszystkich znanych zwartych archiwaliach proweniencji miejskiej dotyczących Bydgoszczy z okresu staropolskiego, a której celem było ustalenie wszystkich osób związanych z miastem, znajdujemy nazwisko Żorawski. Jednak według ustaleń autorki żebrak Jakub był pierwszą chronologicznie osobą o tym nazwisku w Bydgoszczy. Innego Żorawskiego („famati Mathiam”), zgodnie z danymi zebranymi przez autorkę, wspominają źródła w latach: 1646, 1648 i $1659^{29}$. Raczej wątpliwe, biorąc pod uwagę treść dostępnego nam testamentu, aby osoby te były ze sobą spokrewnione. Ponadto okazuje się, że ustalenia dotyczące drugiego z Żorawskich są nieścisłe, przynajmniej jeśli chodzi o dwie pierwsze chronologicznie wzmianki źródłowe ${ }^{30}$.

${ }^{27}$ Ibid.

${ }^{28}$ Ibid., k. 41v. Darowizna ta jest o tyle ciekawa, że ruchomości, które miały kontakt z osobą zmarłą podczas pomoru, podlegały zniszczeniu przez spalenie, ponieważ dystrybucja takich dóbr przyczyniała się do rozszerzania epidemii. Wyjątki stanowiły tylko rzeczy cenne, które podlegały odkażaniu, zob. Andrzej KARPIŃsKI, W walce z niewidzialnym wrogiem. Epidemie chorób zakaźnych $w$ Rzeczypospolitej $w$ XVI-XVIII wieku i ich następstwa demograficzne, społeczno-ekonomiczne i polityczne, Warszawa 2000, s. 122-123, 191.

${ }^{29}$ M. Czaplicka-Niedbalska, op.cit., s. 440.

${ }^{30}$ Wpisy dotyczące Macieja Żorawskiego pochodzą z ksiąg ławniczych (Acta resignationum oraz Acta Protocollum Actrorum) z lat 1640-1652 i 1656-1659. Problem polega na tym, że w miejscach podanych przez autorkę (konkretne karty) w przypadku lat 1646 i 1648 nie ma żadnych wzmianek na temat Macieja Żorawskiego (jedna zapiska dotyczy zupełnie innych osób, a druga jest niemożliwa do ustalenia, ponieważ nie istnieje karta wskazana przez autorkę). Trzecia zapiska z 1659 r. jest nieistotna dla tejże pracy z powodu swej lakoniczności, por. APB, AMB, sygn. 14: „Acta Protocollum Actrorum", k. 150v; M. CzaplickA-Niedbalska, op.cit., s. 32, 440. Nie można jednak wykluczyć, że inne źródła, które mogły zawierać wzmianki o Żorawskich, zaginęły lub uległy zniszczeniu. 
Natomiast wymienionych w testamencie „powinowatych” żebraka nie sposób zidentyfikować. Wydaje się, że kontakt J. Żorawskiego z krewnymi żony był ograniczony przez którąś ze stron do minimum, ale nie został zerwany. Nie wiadomo również, czy żebrak nie posiadał innej bliskiej rodziny, z którą jednak - biorąc pod uwagę zapisy testamentu - raczej nie miał kontaktu.

Co wiadomo natomiast o „domku” żebraka? Wydaje się pewne, że nieruchomość znajdowała się w obrębie murów miejskich ${ }^{31}$. Jednakże dokładniejsze zlokalizowanie tego obiektu jest praktycznie niemożliwe, gdyż w testamencie nie pada nazwa ulicy, nie są też wymienione żadne wskazówki topograficzne, które mogłyby wskazać usytuowanie tegoż „domku”. Określenie „domek” występuje na kartach Liber testamentorum civilium Bidgostiensium kilkakrotnie, rzadziej niż termin „kamienica”. Najczęściej w testamentach bydgoszczan z przełomu XVI i XVII w. pojawia się jednak określenie „dom”. Słowo „domek” wskazuje, że nieruchomość była niewielkich rozmiarów i nieokazała, biorąc pod uwagę jej materialną stronę. Nie oznacza to wszakże, że tego typu budynki nie funkcjonowały na najbardziej reprezentatywnych ulicach miasta, takich jak Długa (główna ulica miasta) ${ }^{32}$. Tym samym nie sposób obecnie wskazać miejsca usytuowania nieruchomości należącej do J. Żorawskiego.

Równie trudny do określenia jest sposób, w jaki żebrak wszedł w posiadanie wspomnianego „domku”. Ówcześnie w stan posiadania nieruchomości miejskiej można było wejść drogą kupna, przez dziedziczenie lub darowiznę. Mało prawdopodobne, aby J. Żorawski zakupił ów „domek”. Jeśli miałoby to miejsce, musiałby to uczynić przed swoją ewentualną „pauperyzacją". Bardziej możliwe jest, że otrzymał ową nieruchomość na drodze spadkobrania bądź w ramach innego typu darowizny. Mógł bowiem służyć komuś zamożnemu i za tę „wierną służbę” zostać wynagrodzony. Przypadki hojnego wynagradzania wiernych sług w ówczesnej rzeczywistości nie stanowiły rzadkości ${ }^{33}$. Niestety także ta kwestia pozostanie bez jednoznacznej odpowiedzi.

${ }^{31} \mathrm{~W}$ przeciwnym razie zostałoby to podkreślone. Analiza testamentów znajdujących się w Liber testamentorum civilium Bidgostiensium wskazuje na to, że mieszczanie bydgoscy byli w tej materii dość skrupulatni.

${ }^{32}$ Świadczy o tym Aneks zamieszczony w Historii Bydgoszczy ilustrujący obrót nieruchomościami w Bydgoszczy w latach 1619-1622, przygotowany przez Zenona Guldona. Wynika z niego, że na ul. Długiej istniał „domek drewniany”, który stał się przedmiotem transakcji w 1619 r., zob. Zenon Guldon, Rozwój urbanistyczny i przemiany ludnościowe w latach 1466-1772, [in:] Historia Bydgosz$c z y$, t. 1, red. Marian Biskup, Warszawa 1991, s. 166.

${ }^{33}$ Na przykład w 1610 r. mieszczanin warszawski Grzegorz Węgrzyn podarował swojej służącej część domu, zob. A. KARPIŃski, Pauperes, s. 183. Jedyną zamożną osobą, o której wiemy, że mogła utrzymywać z J. Żorawskim jakieś kontakty, był wspomniany rzeźnik Michał Toboła, u którego służył syn naszego testatora. Sądząc po testamencie Michała Toboły, spisanym 27 VII 1596 r., był on człowiekiem pragnącym jedynie zabezpieczyć przyszłość swoich dwóch córek. Potrzeby innych osób, jak chociażby drugiej żony, pasierba czy ubogich szpitalnych, schodziły na boczne tory. Stąd raczej nie należy upatrywać w nim tego, który mógłby ów „domek” Żorawskiemu podarować, zob. APB, AMB, sygn. 18, k. 93v-95v: „TESTAMENTUM OLIM MICHAELEM TOBOLA”. 
Zupełnie innym problemem jest sprawa utrzymania się testatora przy nieruchomości. Możliwe, że J. Żorawski nie mieszkał sam, wynajmował ludziom podobnej kondycji miejsce w swoim „domku” i z tego rodzaju dochodów opłacał stosowne podatki miejskie.

Warto się zastanowić nad miejscem J. Żorawskiego w hierarchii społecznej. Jak wspominałem, testator przed podjęciem żebraczej doli był zapewne uboższym mieszkańcem miasta. Z całą zaś pewnością umarł jako żebrak. Fakt wpisania testamentu Żorawskiego do księgi miejskiej nie zmienia jego statusu społecznego, a czynność prawna została najpewniej zainicjowana przez rodzinę Bałów, której członkowie odnosili oczywiste korzyści z powstania takowego dokumentu. Przypomnę, że już w nagłówku testamentu pisarz zaznaczył - wpisując słowo „medici” - że jest to akt ostatniej woli żebraka. Dlatego też nie należy windować pozycji Żorawskiego, gdyż mowa o osobie, która nie utrzymywała się z pracy własnych rąk i żyła z żebraniny (przynajmniej u schyłku życia). To w oczach wielu współczesnych dyskredytowało człowieka. Posiadanie nieruchomości w postaci „domku” w obrębie murów miejskich stawiało go wyżej od innych żebraków. Dzięki tej majętności, niezależnie od jej wartości, J. Żorawski stawał się bardziej odporny na ewentualne skutki miejskiego ustawodawstwa antyżebraczego. Warto podkreślić, że testator poczuwał się do udzielenia jałmużny na rzecz ubogich ze szpitali. Z jednej strony świadczyło to o jego stabilnej pozycji ekonomicznej (miał bowiem co dzielić), ale też o tym, że nie zapominał - samemu będąc żebrakiem - o innych ludziach ubogich.

Dotychczas w polskiej literaturze historycznej o żebrakach w epoce nowożytnej wspominało się niejako przy okazji omawiania problemów: szeroko rozumianych „ludzi luźnych”, opieki społecznej czy badań nad najniższymi warstwami społeczeństwa ${ }^{34}$. Rzecz ta wydaje się zrozumiała w kontekście znanych dotąd źródeł, gdyż tych dotyczących żebraków jest niewiele i zwykle mają one charakter lakonicznych wzmianek. Bez wątpienia testament J. Żorawskiego powiększa zasób

\footnotetext{
${ }^{34}$ Poniżej podaję ważniejsze publikacje, niewymienione we wcześniejszych przypisach, odnoszące się do problemu żebractwa w Rzeczypospolitej: Zbigniew GóraLski, Działalność charytatywna w Polsce przedrozbiorowej, Kraków 1973; Bronisław GeremeK, Obraz kondycji żebraczej w polskiej literaturze XVI i XVII wieku, [in:] Kultura polska a europejska, red. Maria BoGUCKA, Jerzy KowecKI, Warszawa 1987, s. 131-146; Zdzisław Kropidıowsкi, Urzędy i urzędnicy powołani do opieki nad ubogimi w Gdańsku od XVI do XVIII wieku, [in:] Nędza i dostatek na ziemiach polskich od średniowiecza po wiek XX, red. Janusz SzTetYєєo, Warszawa 1992, s. 93-126; Andrzej KARPiŃski, Opieka nad chorymi i ubogimi w miastach polskich $w$ czasie epidemii w XVII-XVIII wieku, [in:] Charitas. Miłosierdzie i opieka społeczna $w$ ideologii, normach postępowania i praktyce społeczności wyznaniowych w Rzeczypospolitej XVI-XVIII wieku, red. Urszula AugustyniaK, Andrzej KarPIŃsKI, Warszawa 1999, s. 221-244; Zdzisław KropidŁowski, Organizacja dzieł miłosierdzia chrześcijańskiego w Gdańsku w XVI-XVIII wieku, [in:] ibid., s. 139-160; Jakub GolDBERG, Bieda oraz dobroczynność Żydów polskich w Dawnej Rzeczypospolitej, Kultura i Społeczeństwo, t. 43: 1999, nr 1, s. 4-17; Piotr Grochowski, Dziady. Rzecz o wędrownych żebrakach i ich pieśniach, Toruń 2009, s. 93-138; Anna JabŁoŃsKa, Siedemnastowieczni pauperes $w$ świetle źródeł kościelnych z terenu archidiakonatu gnieźnieńskiego, [in:] Bieda w Polsce, red. Grzegorz Miernik, Kielce 2012, s. 45-56; Sylwia KonARsKA-Zıмnicka, Średniowieczna jałmużna - oznaka pobożności czy rozrzutności?, [in:] ibid., s. 23-33.
} 
wiedzy w kwestii biedy i żebractwa w nowożytnej Rzeczypospolitej. Należy wyrazić nadzieję, że dalsze poszukiwania archiwalne przyniosą podobne znaleziska źródłowe, które pozwolą w szerszym kontekście spojrzeć na przypadek żebraka z Bydgoszczy. Póki co, casus Jakuba Żorawskiego, mającego „domek” w Bydgoszczy, wydaje się wyjątkowy.

\section{ANEKS ŹRÓDŁOWY*}

Archiwum Państwowe w Bydgoszczy, Akta miasta Bydgoszczy, sygn. 18: „Liber testamentorum civilium Bidgostiensium", k. 40v-41v.

[k. 40v]

\section{TESTAMENTUM OLIM PROVIDI JACOBI ZORAWSKI MENDICI}

In Nomine Domini Amen. Anno eiusdem Millesimo Quingentesimo Octogesimo Quinto die Dominicam quarta adventus domini [22 XII 1585 r.], hora octava ante meridiana medy horology. In praesentia famatorum testium infra de nomine et cognomine scriptorum providus Jacobus Zorawski in domo sua sedens vestitus caligatus calceatusque. Licet corpore languidus et valetudinarius sanus facerem mente et rationis [k. 41] bene compos bona deliberatione maturoque consilio prehabito obtinentque per sententiam iuridicam, quod cum suis bonis perexegnis mobilibus et immobilibus facere et disponere possit. Ad hoc precumstodiens ne lites controversie inimicine do dictis bonis suis relictis omiantur. Sedem bene placitum sue voluntatis hoc condidit testamentum ut talem ordinationem sue ultime voluntatis fecit.

Napirwy duszę swoją grzeszną w ręce Pana Boga Wszechmogącego polecił, a ciału pogrzeb prze[z] Stanisława Bałę komornika i jego żonę Katarzynę, ich własnym nakładem uczynić prosił, bo on, będąc żebrakiem ułomnym, powiedział, dostatku tego nie mieć, który pogrzeb na cmentarzu u fary sobie obrał. Item zeznał, że [p]omienionemu Stanisławowi Bale i Katarzynie, obu małżonkom, jest winien 10 złotych polskich długu, któremi go żywili, i w niedostatku, w niemocach jego częstych wspomagali, które t[o] 10 złotych na domku swoim i drugi[ch] jakichkolwiek majętności nieruchomy[ch] im zapisuje i czasy wiecznymi ubezpiecza. Z któ-

\footnotetext{
* Podczas opracowywania aneksu źródłowego wykorzystano instrukcję wydawniczą: Kazimierz LEPszY, Instrukcja wydawnicza dla źródeł historycznych od XVI w. do poł. XIX w., Warszawa 1953 (http://mikmach.hg.pl/zrodla2/lepszy.html\#lcz234182230-pierwsza---podstawa-wydania; dostęp z dnia 28 VI 2013 r.).
} 
rego domku jeszcze na miłosierne uczynki za jałmużnę, której od ludzi przez kilkanaście mało lat używał, 7 złotych polskich ubogim na obiady przez tegoż Stanisława Bałę i Katarzynę małżonkę tym obyczajem odkazał, że na każdy rok po talarze starym obiad na ubogie wyprawić mają aż do wydania [p] omienionych 7 złotych. Także też z tego domku ten to Jakub Żorawski na najbliższe swe powinowate 3 złote odkazał, które ten to Stanisław Bała i z żoną swoją, gdy się ci przyjaciele bliżsi ozową, podług jego woli wydać mają, a oni in requates dimisiones mają jemi się ${ }^{\mathrm{a}}$ rozdzielić, a gdy to ten Stanisław Bała i z żoną swoją uczyni, przy domku i drugich dobrach nieruchomych, jako swoich własnych, mają zostać i potomkowie jeich. Ipsosque viros heredes instituit hecque omnia onerando conscientiam ipsorum secunduus suam ultimam voluntatem adimplere tenebuntur quod in se susceperunt. Item pościółkę swą ubogą ze wszytkimi aparaty, jako na żebraka należy, Katarzynie komornicy za wymierne posługi i dobrodziejstwa, któremi u czasu jego choroby jako ojcu czyniła, odkazał. Także szatki swoje wszytkie [k. 41v] Stanisławowi Bale wskazał, a chłopięciu Stanisława, co go wodziło, za jego pracą i służbę sukienkę swoją i żupkę, także i insze rzeczy, które przy Michale Tobole, po śmierci syna jego Jana, morowym powietrzem zmarłego, pozostały, to wszytko temu chłopięciu odkazał ${ }^{\mathrm{b}}$. Praeterea in executores dicti sui testamenti seu ultime voluntatis fecit instituit et une proprio nominavit honestos Albertum Wydawius notarium Civilem et praememoratum Stanislaum Bala quibus percepit vagant et omnia et singula legata inuxta praedictum suam ordinationem post mortem suam distribuant ut extradant. Acta sunt hec anno die ut supra praesentibus famatis Francisco Swincik viceadvocato, subdelegato Alberto notario, Joanne Mattheiek Ministeriali quiale (?) Paulo Doniczka sartore, Sebastiano Urbancik figulo, Stanislao Bala testibus ad praemissa vocatis et rogatis supra, quo Juri memoriale solutum est.

\footnotetext{
a Słowo nadpisane.

b Odwołanie do marginesu. Napisano tam: „jeśli dobrze prawi, tedy jemu [od]kazuje et conexit”.
} 
DER FALL DES BROMBERGER BETTLERS JAKUB ŻORAWSKI. EIN BEITRAG ZUM PROBLEM DES BETTELWESENS IN DER FRÜHNEUZEITLICHEN RZECZPOSPOLITA

\section{Zusammenfassung}

Schlüsselbegriffe: Bromberg, Testament, Armut, städtische Arme, pauperes, Arme in altpolnischer Zeit

Testamente von Personen aus den Randgruppen der Gesellschaft sind auf dem Gebiet der alten Rzeczpospolita eine Seltenheit. Ganz besonders gilt dies in Bezug auf Bekundungen des letzten Willens durch Bettler. Bislang haben sich in solchen Dokumenten noch keinerlei Hinweise auf den Besitz von Immobilien durch Bettler gefunden. Deswegen erscheint der Fall des Jakub Żorawski, eines Bettlers aus Bromberg, als Ausnahmeerscheinung, denn das von ihm hinterlassene Testament bezeugt, dass er Besitzer einer kleinen Immobilie („Häuschen“) innerhalb der Stadtmauern gewesen war. Auf der Grundlage seines Testaments lassen sich auch bestimmte Fakten seines Lebens rekonstruieren.

\section{THE CASE OF JAKUB ŻORAWSKI - A BEGGAR FROM BYDGOSZCZ: THE CONTRIBUTION TO THE PROBLEM OF BEGGARY IN THE RZECZPOSPOLITA OF THE EARLY MODERN PERIOD}

\section{Summary}

Key words: Bydgoszcz, last will, poverty, impoverished city inhabitants, paupers, the poor in Old Polish times

The last wills of people from the marginalised strata of society in the old Rzeczpospolita did not constitute a frequent phenomenon; even less frequent were last wills made by beggars. So far no evidence has been found of a beggar who owned any real estate. For this reason, the case of Jakub Żorawski, a beggar from Bydgoszcz, is exceptional, for he left a will from which it may be concluded that he owned a small parcel of real estate ("a small house") within the city walls. On the basis of his last will some facts from his life may be reconstructed. 